\title{
Urban Growth and Front Development on Risk Zones: GIS Application for Mapping of Impacts on Yaounde North Western Highlands, Cameroon
}

\author{
Ojuku Tiafack, Alex Mengue Mbon \\ Geography, University of Yaounde, Yaounde, Cameroon \\ Email: tiafackojuku@yahoo.co.uk,almengue@yahoo.fr
}

How to cite this paper: Tiafack, O., \& Mbon, A. M. (2017). Urban Growth and Front Development on Risk Zones: GIS Application for Mapping of Impacts on Yaounde North Western Highlands, Cameroon. Current Urban Studies, 5, 217235.

https://doi.org/10.4236/cus.2017.52013

Received: June 1, 2017

Accepted: June 27, 2017

Published: June 30, 2017

Copyright $\odot 2017$ by authors and Scientific Research Publishing Inc. This work is licensed under the Creative Commons Attribution International License (CC BY 4.0).

http://creativecommons.org/licenses/by/4.0/

\begin{abstract}
African cities today are confronted with the problem of rapid urbanisation, poverty and land use abuse. Yaounde, the political capital of Cameroon is a victim of this situation. Faced with population growth, competition, pressure and high cost of land in the heart of the city, populations involved in informal services for survival have been displaced by the Yaounde city council and ministry of Housing and Urban Development responsible for urban planning. These victims, many of whom are poor and vulnerable, have occupied marginal and suburban areas, some of which are risk prone environments. Mbankolo, Febe, Carrier, Nkolbisson and Messa areas amongst other in the north west of Yaounde are victims of this spontaneous land occupation characterised by urban front development. The victims comprising poor urban dwellers are dominated by migrants from western Cameroon and other regions of the country that have resisted returning to their place of origin. Urban disorder and land use abuse marked by uncontrolled deforestation, wetland occupation and soil degradation for settlement, agriculture and commerce is high in the newly occupied zones necessitating research and measures to pre-empt future disaster in this area. Faced with the volume of data to handle, this work exploits Geographic Information System techniques to map out this phenomenon in Cameroon for decision-making. The data exploited are sourced from field observations and surveys, analysis of remotely sensed data (satellite images of different periods, GPS data) and consultation of administrative and scientific documents (topographic maps, articles and reports) published on the area of research.
\end{abstract}

\section{Keywords}

Urban Growth, Poverty, Land Use Abuse, Risk, Yaounde 


\section{Introduction}

Urban expansion accompanied by front development at disaster prone zones and suburbs is becoming an issue of preoccupation in many towns in developing countries. In Cameroon urban fronts are semi urban landscapes projecting from the heart of the town towards the peripheries marked by unplanned settlements that are poorly equipped with basic infrastructures, accessible by untarred roads and footpaths. Sometimes these fronts have a high concentration of newly constructed houses occupied by relatively low income classes. Because these suburban areas do encroach into risk prone lands prohibited from human occupation by the government, research is indispensable to document their dynamics and the risk associated (Assako Assako, 1998). Government in its efforts towards urban renewal and control of urban disorder in the city centres has resorted to reprisal. Urban disorder often results from rapid population growth, expansion of population activities and service into roadsides, occupation of state property and marsh lands. Majority of the populations affected in the process of urban renewal are the poor whose financial status and living conditions cannot permit them to afford for the high cost of land, services and housing provided by the state upon renewal of the town. These poor populations and other victims of urban reforms have migrated and resettled in risk zones, marginal lands and the outskirts of the town leading to the development of urban fronts. In these emerging urban fronts the disorder transferred from the heart of the city has been installed leading to anarchy, land degradation, deforestation, disasters, tension and land use conflicts. The Yaounde North Western Mountains and valleys in the Yaounde 1, 2 and 7 Sub Divisions in Cameroon upon which this study is centred are victims of this spontaneous urban growth problem. These urban fronts have developed in the last two decades following the rise in urban poverty, haphazard occupation of public domains and repressive measures to curb rising indecency in the city of Yaounde. Unlike front development along the steep slopes of North Western Yaounde leads to increase in risk of rock falls, erosion and landslides, urban encroachment into swampy areas and valleys result to flood disasters. The outcomes from flood history have been the lost of human lives, food crops and property. Government responses to these urban disorder and resulting negative impacts have been unsuccessful. The risk of an impending urban disaster is high faced with the exponential growth of the population, activities expansion and settlements encroachment into these marginal lands. This work therefore investigates into the situation by using GIS tools for data collection and analysis to facilitate decision-making by stakeholders.

\section{Yaounde North Western Mountains: Location, Site and Characteristics}

Geographically the Yaounde North Western Mountains lie between latitudes $3^{\circ} 47^{\prime} \mathrm{N}-3^{\circ} 57^{\prime} \mathrm{N}$ and longitude $11^{\circ} 10^{\prime} \mathrm{E}-11^{\circ} 44^{\prime} \mathrm{E}$ as per WGS84 coordinate system. The site is situated in the West of Yaounde-the political capital of Cameroon. This area is found in the Yaounde 7 and 2 and 1 Sub Divisions created by 
presidential decree $\mathrm{N}^{\circ}$ 2007/117 of 24 April 2007 (Figure 1 and Figure 2).

The study site is diversified in physical characteristics. The Yaounde Highlands are a compartment of mountains that form a defensive wall along the western part of Yaounde commonly referred to as "la ville de Sept Collines". These seven mountains are Mt Febe (1073 m), Mt Mbankolo (1098 m), Mt Messa (1015 m), Nkolondom (1221 m), Akok-Ndoe (967 m), Mbekoum (953 m) and Minloua (966 m) (Figure 1 and Figure 2). Yaounde North Western Mountains cover a surface area of over 5600 hectares.

The site under study has convex and steep slopes of over 15\%. Some compartments are hilly comprising extensive rock outcrops and remnants of degraded

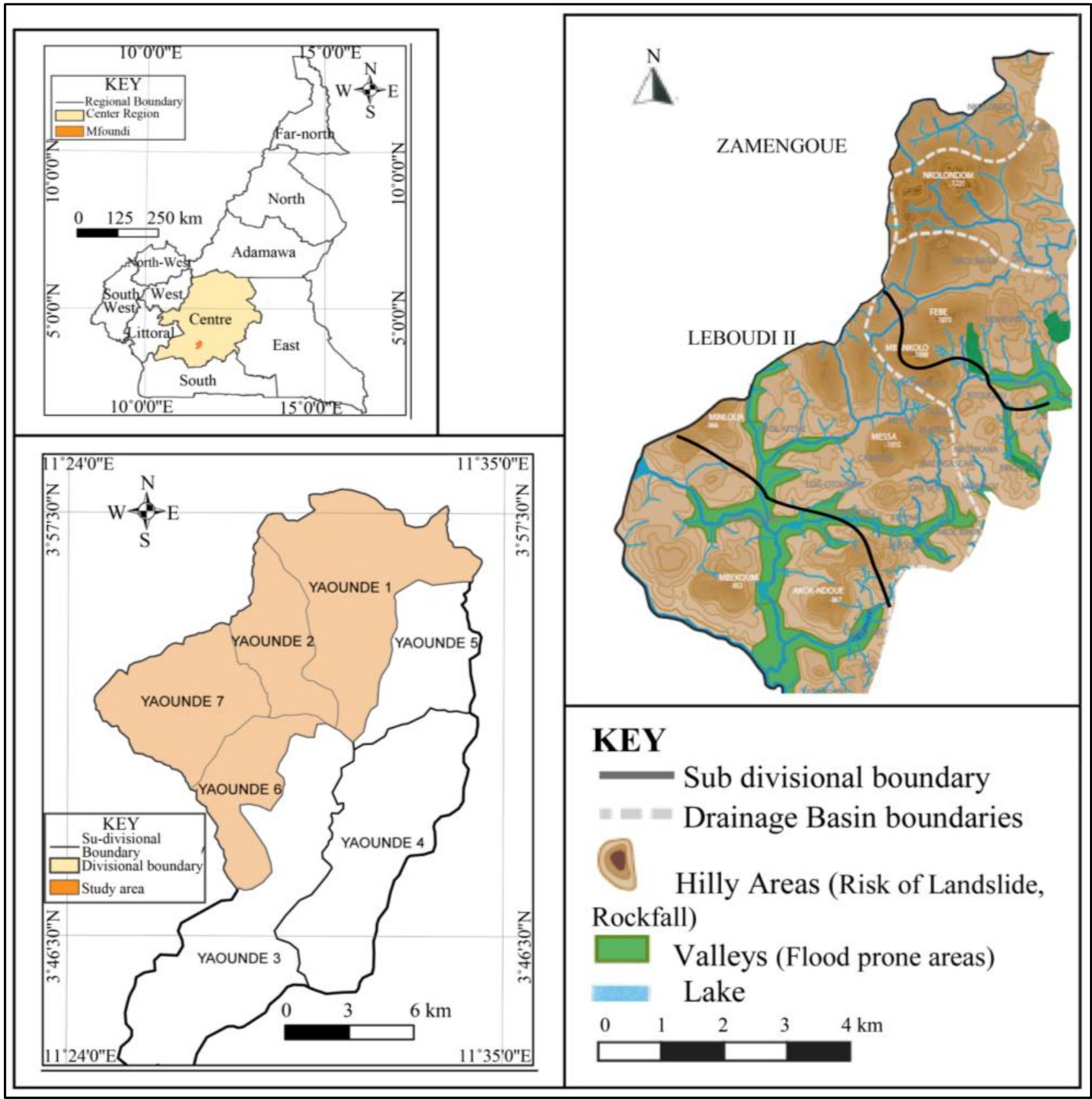

Figure 1. The north west mountains of Yaounde in Cameroon. 


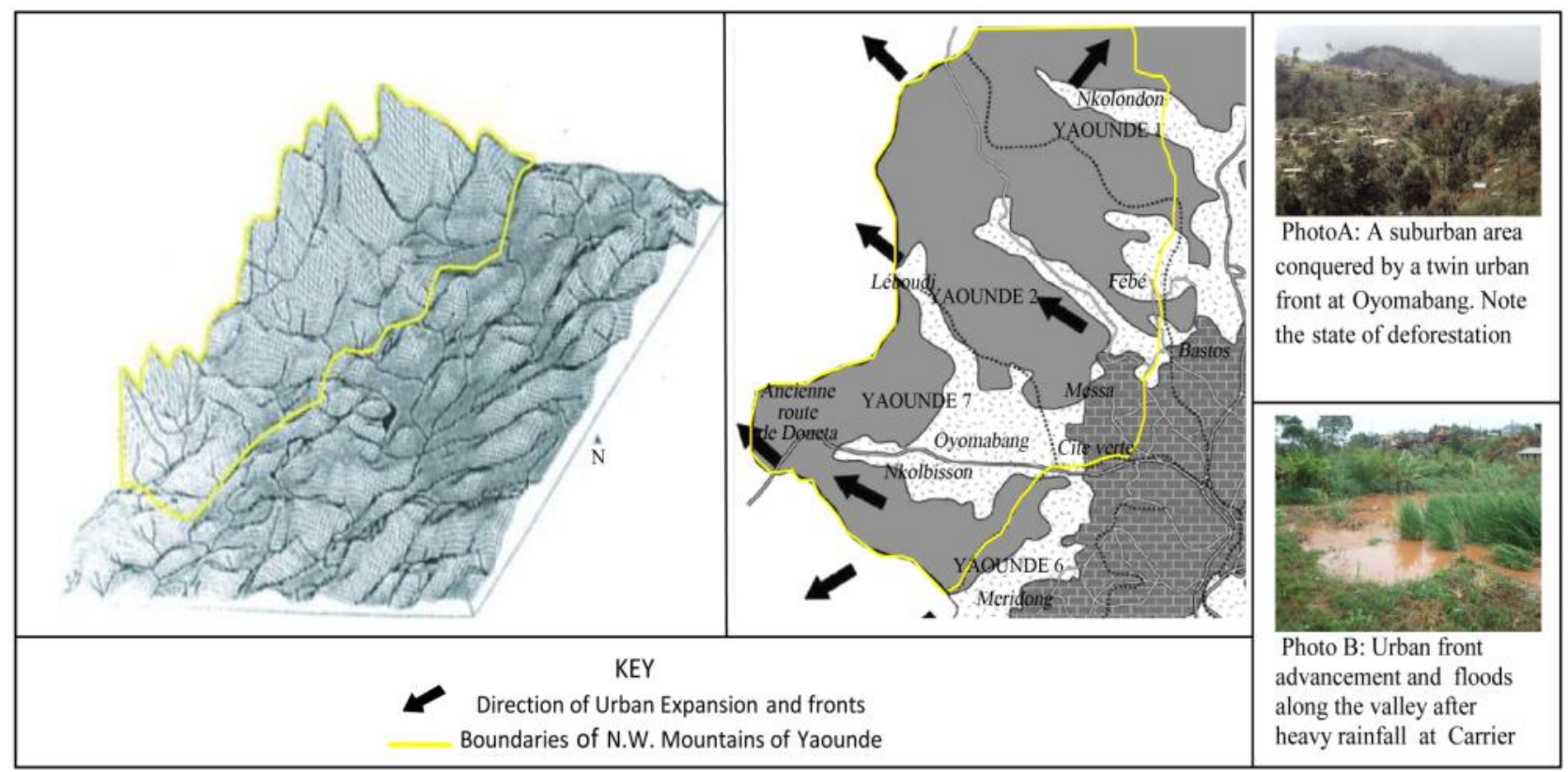

Figure 2. Sectional views of the North Western Mountains of Yaounde, directions of urban expansion and risk. Source: MINDUH and CUY (2008).

forest. Erosion is also very intense along some parts of the mountains due to heavy rainfall in the rainy season and pressure from human activities. The mountain chains are interrupted by densely occupied valleys within which urban fronts have emerged and extended to colonized hill summits and urban outskirts. Many streams and rivers flowing across Yaounde city take their rise from these uplands amongst which are the Mfoundi, Ebozock, Mefou, Mintetomo, Abiergue and Djoungolo.

Urban population installations on this area predispose the people and activities to many hazards. Human presence is marked by intense agricultural activities along steep slopes, dense concentration of houses and buildings along the slopes, valleys and wetlands. Also, the installation of small scale businesses premises and enterprises, public utilities and infrastructure (schools, health services, churches) along areas recurrent to floods, rock falls, soil creep, mass wasting and landslides is visible. These risk factors coupled with the development and continuous expansion of urban fronts without the intervention of urban planners, decision makers and other stakeholders pose a problem.

The factors of human occupation of the area and outcomes are linked to urban development projects. It is in this part of the town that the former Yaounde- Douala national road now earmarked as a highway passes. Land speculators have occupied much of these lands leading to the emergence and spread of unplanned quarters which are poorly equipped with basic infrastructures and services. These quarters comprising Carriere, Elig-Otoumba, Oyomabang, Angono, Messa, Mbankolo, Oliga, Plateau, Febe, Nkol Afeme, and Leboudi II at the neighbourhood have several unplanned urban fronts that project unsustainably towards the risky valleys and steep slope areas Figure 1 and Figure 2. 


\section{Methodology}

\subsection{Data Used}

The data used for this paper has been collected from several sources. These include in-depth fieldwork, analysis of remotely sensed data (multi-date satellite images, Global Positioning System data), and consultation of administrative and scientific documents (topographic map sheets, articles, reports) published on Yaounde.

Several data sets were used for identification, mapping and assessment of flood, landslide and rock fall prone areas. Firstly, Satellite and topographic data exploitation and analysis were done using specialised softwares (Erdas Imagine and Arc GIS) for mapping and modelling of the study matrix before ground surveys. Maps of North Western Yaounde Mountain perimeter were extracted from Quickbird images and the digital elevation model (DEM) produced using contour maps, and spot heights. This facilitated the identification and observation of slopes, valleys, wetlands and urban front advancement. This phase preceded ground survey works done with the Global Positioning System (GPS) receiver for location of habitats, infrastructure and equipments at risk zones. A geodatabase in Arc GIS environment was done for the study area. Secondly, a comprehensive household survey was conducted in the study sites to collect data on population activities and the vulnerability of each household to floods, landslides, rock falls and mass wasting. Thirdly, vulnerability was assessed for each slope and flood prone areas using population habitat data and a direct census of services installed at swampy areas and mountain slopes. Several plates and photos have been used to illustrate ground truth data.

To detect flood and landslide prone areas, field surveys were done with a team of researchers employed. In quarters where floods are recurrent, the height of illegal buildings were measured, services and infrastructures vulnerable to floods counted and located with the GPS receiver (Plate 1).
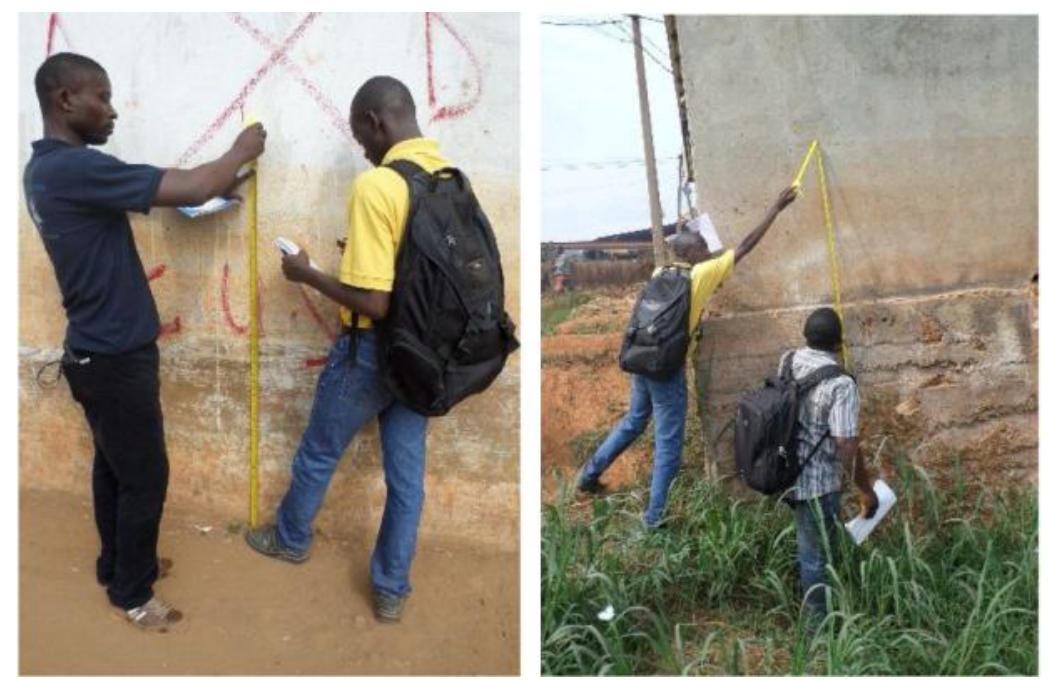

Plate 1. Field survey works at risk zones forbidden by the Yaounde city council for construction. Source: Authors 2016. 
During this exercise, a questionnaire designed for the study was administered among the people living in flood areas and steep slopes. The questionnaire sort to obtain information about the socio-economic life of the occupants, history of occupation of the lands, impacts of hazards on their daily life, and reasons for settlement in the forbidden sites. The responses were analysed.

\subsection{Urban Growth History and Front Development in Yaounde}

Yaounde was created by the Germans in November 30th 1889 (Mveng, 1985; Bopda, 1985). Before this creation the site was occupied by a botanical and agricultural research centre and later a German military station (Bezirksamt, April 1905 cited by Franqueville, 1984). It became the political capital of Cameroon in 1909 before the First World War in 1914. The Germans located the town on a geo-strategic position comprising 7 hills on an average altitude of 750 metres (Figure 1 and Figure 2). It's situation in the heart of the tropical rainforest, $200 \mathrm{kms}$ from the Atlantic Ocean and the middle of Cameroon made it further secure and safe.

The urban growth of this town from creation has been spectacular and marked by haphazard urban fronts development. Urban growth in Yaounde like other towns in the world has all through been influenced by population growth (natural increase, internal and external migration) and service and space expansion, Vennetier (1973). Yaounde town was initially a hamlet comprising some 300 inhabitants made up mostly of Ewondo (indigenes). By 1958 this population increased to 58,000 , then progressed to 560.785 in $1985,1.5$ millions in 2002, and 1.9 millions in 2005 (BUCREP, 2005). This population which of recent has evolved to 2.3 millions (BUCREP, 2010) is spread over 15,000 hectares (km). The population of the town doubles after every 8 to 9 years. With an exponential growth of about $4.1 \%$ per annum, Yaounde exceeds other towns in Cameroon and is typical of the fastest growing towns in the world. Contrary to European cities the urbanization of Yaounde has been sagregatory, appearing first in interfluves, then colonizing the hill slopes and subsequently extending into depressions.

This spatial growth of the town was at first concentric but has evolved into a dispersed model characterized by multi directional co-urban fronts development (Figure 3). The population and urban growth of Yaounde is attributed to natural increase and migration which increases $4 \%$ to $5 \%$ annually since 2000 . Rural-urban Exodus and immigration from abroad has greatly contributed to this population and urban growth. About 25\% of the urban population of Cameroon is located in Yaounde (NIS, 2007). In the last 6 decades, the population of Yaounde has increased 10 folds. This increase has been steady leading to urban build up and extension towards the major access roads into the town only interrupted by valleys and hills since 1885 to present (Figure 3 and Figure 4). Slope and valley colonization by urban fronts are typical of Elig-Otoumba and Messa neighbourhoods (Figure 4).

As seen on Figure 4, the urban landscape of Yaounde has evolved over the years. The present morphology has a fish shape. Between 1885 and 1941, the growth was concentric and remained steady up to 1974 when the expansion was 


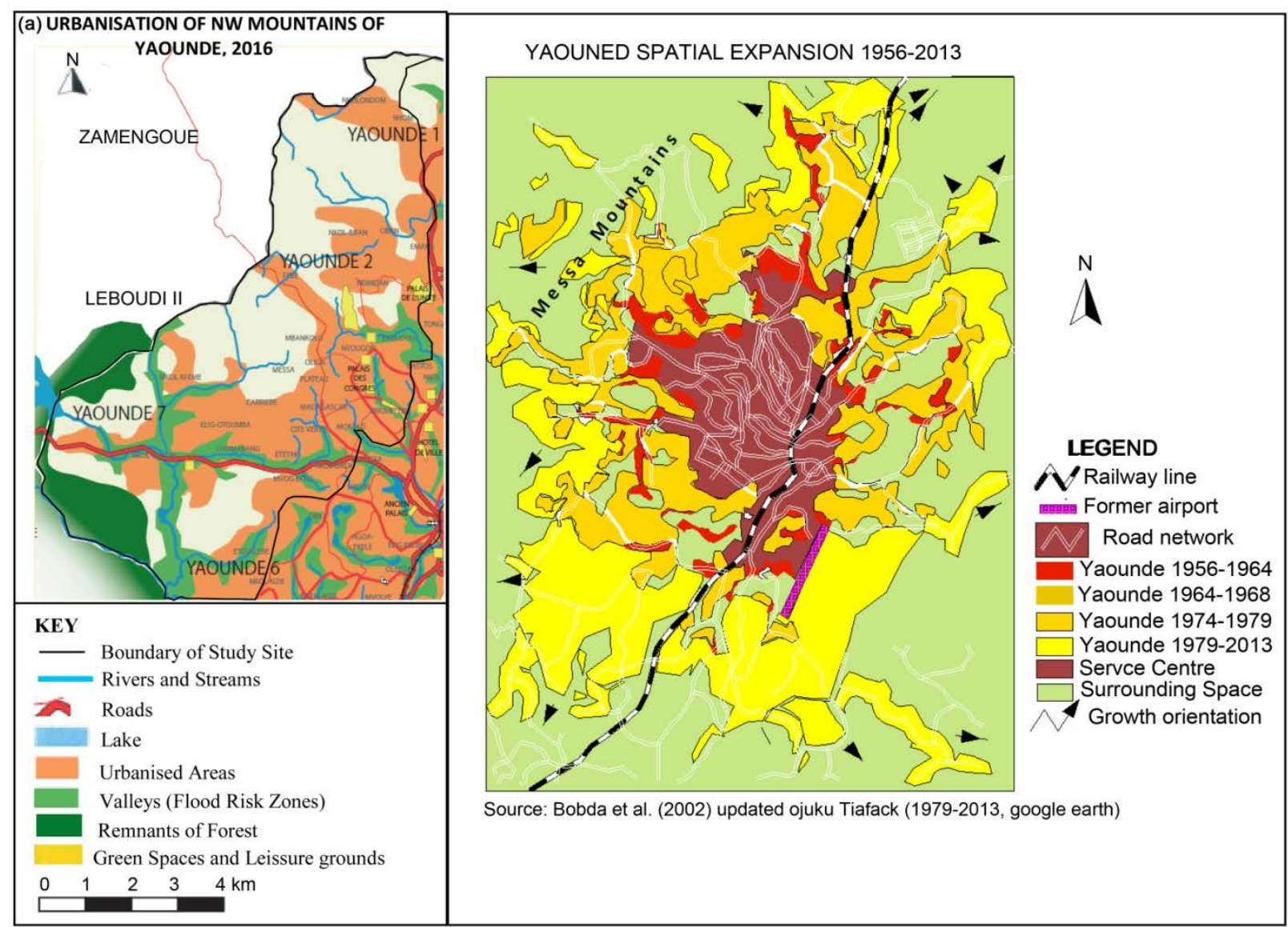

Figure 3. Spatial evolution of Yaounde (1956-2013) and urban fronts dynamics on study sites, 2016.

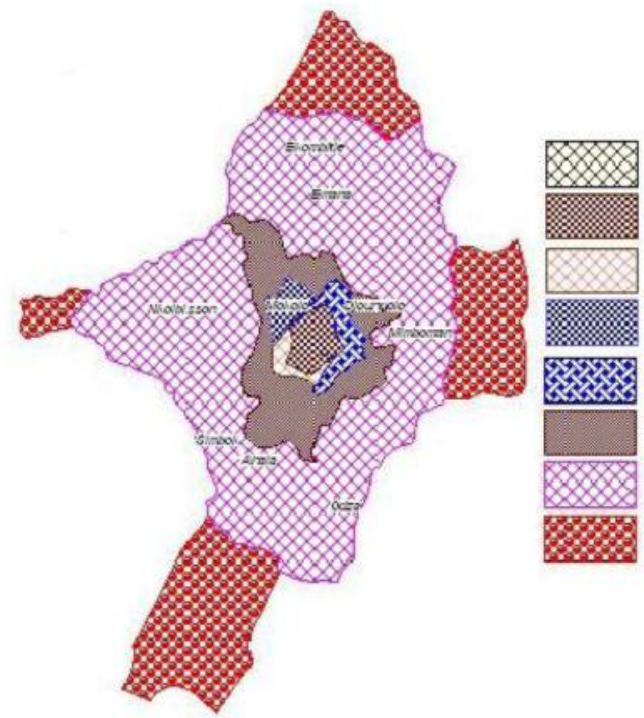

Station 1885-1

1925-1934

1934-1941

1941-1948

1948-1956

1956-1974

1974-1992

$1992-2000$

\section{Spatial Growth of Yaounde from 1885 to 2000}

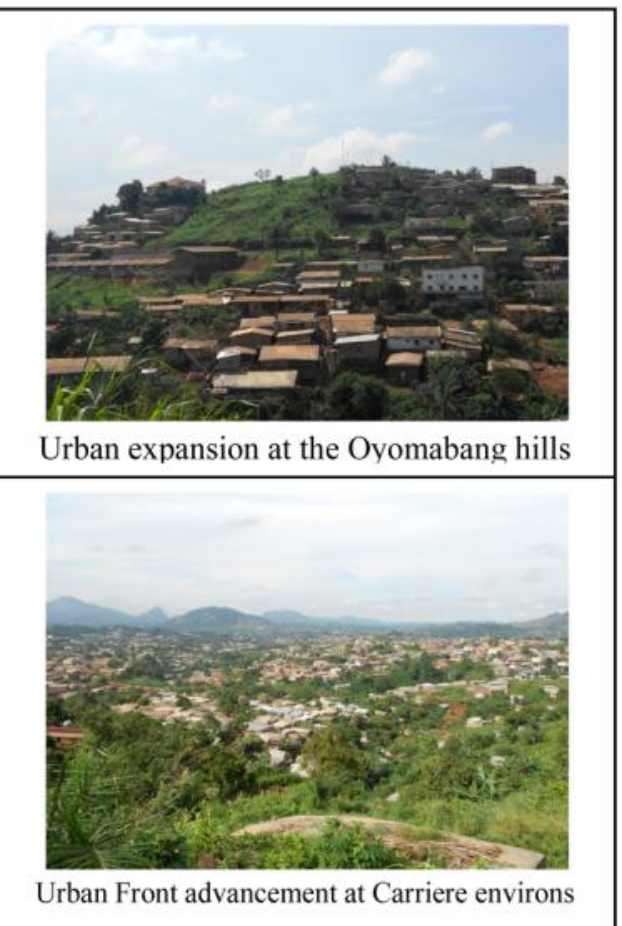

Figure 4. Urban Growth of Yaounde and risk zone colonization. Source: Map adopted from Tchindjang et al. (1988) and photos by Ojuku (2014). 
derailed by the Yaounde Mountains. The morphology from 1956 to 1974 resembled a crooked map of Cameroon tilted southwest. By 1974 and 1992, the spread of the city was relatively uniform in all directions bearing a resemblance of the map of Chad. Since this period the growth and expansion have been northward, southward, eastward and timidly westward along the major roads entering into Yaounde. Conspicuous is the difficult expansion towards the west due to the presence of the mountain chains upon which the study is focused. Hilly areas formerly shaded by vegetation that protected the soils, animal habitats and underground from destruction have been occupied by habitats, farmlands, urban equipments and infrastructures.

This rapid population growth and urban expansion has also led to negative socio-economic outcomes. These include pressure on land leading to rise in land value and rents in the city centre, shortage of affordable houses, unemployment problems, poverty, natural resource exploitation (forest for fuel wood and wood for construction works, rock harvest for building of houses), population settlement at risk zones and urban peripheries for economic activities (small scale agriculture and business enterprises).

\subsection{Urban Front Development and Stakes}

Two types of urban fronts exist on the Mountains of Yaounde. The first is vertical front marked by urban expansion into marsh lands or valleys and hill slopes or summits. The second is horizontal urban fronts characterised by urban spread and occupation of the peripheries. In each of these fronts, risks of environmental or socio-cultural nature are frequent necessitating government intervention (Figure 3). Vertical front development places the population in a dilemma of two hazards. The first is vulnerability to floods and loss of human lives and property when population and services are installed in wetlands or valleys that are periodically flooded (Plate 2). The second is risk of landslide, soil erosion, mass movement and rock fall hazards that destroy crops, property and human lives upon occurrence (Plate 2). Hazards resulting from horizontal urban front development are rampant land use conflicts between the local population (Betis

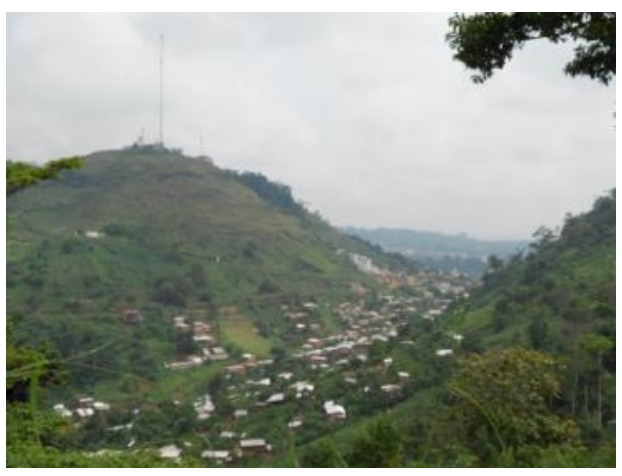

(a)

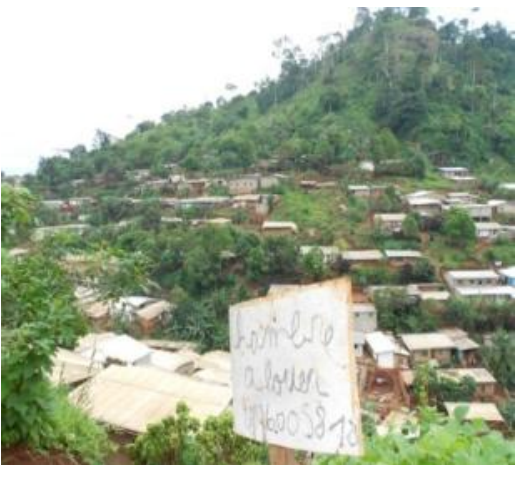

(b)

Plate 2. Urban Front Advancement along a valley at the piedmont of Mt Mbankomo and a slope along Mt Carriere. (a) Colonisation of a drainage basin and flood. (b) Occupation of steep slope and risk at Carriere. Source: Ojuku, 2014. 
and Bulus) and other Cameroonian groups or foreign migrants. The local population is often accused of selling the same piece of land to several persons commonly referred to as "double dealing". This situation resulting from high demand for land and rents due to urban population growth often leads to conflicts, social tension and disputes, destruction of property and legal proceeding in court.

\subsection{Determinants of Urban Front Development}

Fronts development in the study sites are influenced by many drivers. These are presence of a road network, demand for land, agricultural activities, development projects (schools, social housing, health facilities) Figure 5 and resistance to return to the countryside. Areas served by roads are attractive to the population as they facilitate the construction of houses, access to other parts of the town and mobility to the job side. Places where lands are available for sale at affordable prices are also highly solicited especially if inhabited by populations of common ethnic belonging and shared cultures. Many poor urban dwellers solicit risk zones for settlement because of low prices of land. In the North Western Mountains of Yaounde and neighbourhoods for example, a metre square of land

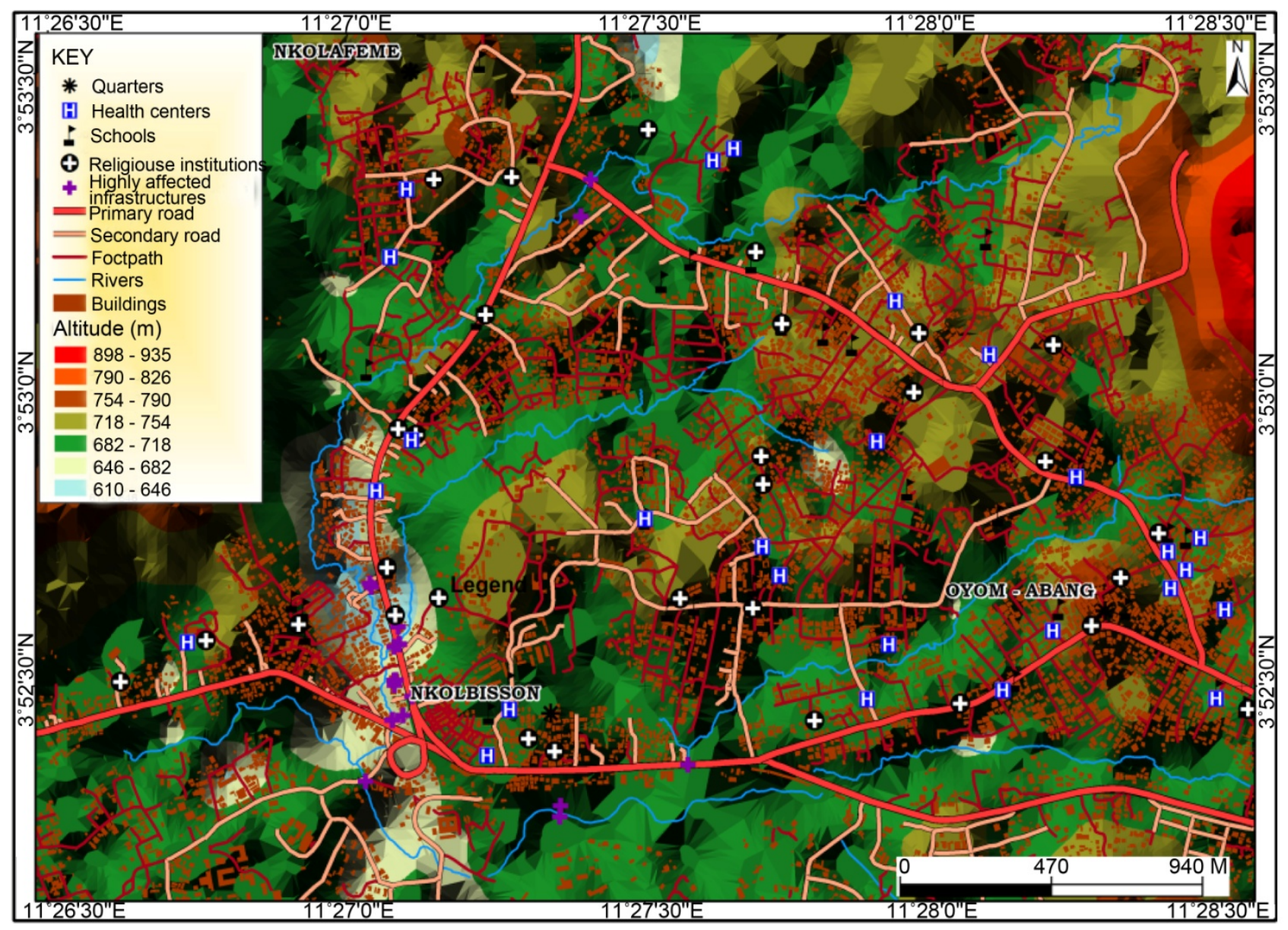

Figure 5. Dense occupation of risk zones at the Oyom Abang-Nkolbisong-Nkolafeme area. Note the encroachment of settlement into the valleys and steep slopes and progress of urban fronts. Source: Realised by Ojuku, Mengue, George, \& Kelvin (2016). 
at the time of the field data collection ranged from 10,000 to 2000 FCFA as against 1000 to $6000 \mathrm{FCFA}$ at the time of first population installation in the zone. The rents of land varied based on the place characteristics, proximity of the land to town and accessibility.

Variables such as food insecurity and new development projects also act as major contributing factors. The high prices of food in the city and problems of food insecurity have obliged many town dwellers in Yaounde to solicit for lands in the outskirts of the town for agriculture. This is the result of rapid population growth, changing land values and high rents in the heart of Yaounde that deviate financial resources for food for other purposes. Also, several fronts have developed in the study area as a result of speculation by urban dwellers of development projects announced to be created in these front areas. In the Mount Mbankolo and Mount Febe zone for instance, a project entitled ORO park earmarked by the Yaounde city council to create a green belt and tourist park in the area in its vision of Yaounde embellishment has attracted many town dwellers and land speculators to occupy the zone. The hills are haphazardly occupied by both the poor and rich populations to benefit from fall outs of this park. As a consequence of this spontaneous population occupation, urban disorder reigns on this site at the watchful eyes of urban development planners. This anarchy announces a second problem likely to be confronted by stakeholders in future which is that of high cost of population displacement from hill slopes and resettlement elsewhere. The compensation of displaced persons to avoid social unrest and resettlement at new sites will likely drain much of state resources in the future.

Also, plans by the Cameroon government to open a highway linking Douala the economic hub of Cameroon to Yaounde the political capital has attracted the development of horizontal urban fronts along these mountainous zones under study. This culture is common in other parts of Yaounde (Ngouanet, 2015) and towns of Cameroon. The announcement of the Yaounde Nsimalen-Highway in Mfoundi Division and the Kribi Deep Sea port at Ocean Division led to high land speculation and development of urban fronts around this environment. Also, the announcement of construction of many sports stadia to host the African nations cup in Cameroon by 2019 has led to population migration for settlement at urban fringes where these projects will take place. Such settlements at the neighbourhoods of Olembe Yaounde, Japoma Douala, Limbe Omnisport stadia and Bafoussam will produce new urban fronts.

Social or family relations, networks and information flow play a very significant role in front development. Many urban dwellers wish to preserve their ethnic belonging, social and professional status by grouping themselves together. It is for this reason that information on land for sale at given urban fronts circulates mostly amongst persons of common backgrounds. Pioneer settlers encourage relatives and tribes men to settle in their quarters. This has led to development of urban fronts that bring together persons of same ethnic groupings. Here there construct cultural halls, elect their village representatives and constitute 
thrift and cultural associations to preserve their culture, interest and identity.

\subsection{Characteristics of Fronts}

Urban fronts in the study site are marked by makeshift grouped houses on water valleys and mountain slopes (Figure 5), dispersed habitats separated by farmlands and houses under construction, lands immatriculated and mapped out for sale, forestlands degraded, quarters not adequately served with basic services and infrastructures (pipe borne water, electricity, telecommunication services, tarred roads and streets. In these fronts quarters established are unplanned. The settlements have houses constructed haphazardly without basic equipments and infrastructures. In flood prone areas and risky slopes, houses observed are constructed using varied material. These are pressed soil blocks, bricks, cement material, wood (Karabouts), mud and metal sheets. The inability of institutions responsible for urban mapping, management and development for the population (MAETUR) and those responsible for provision of low cost housing (SIC) to perform their duties has been a root cause of this disorder Mougoue (1992), Ngouanet (2015). Consequently, disorder reigns along the Yaounde North Western Highlands. Populations in this setting are vulnerable to natural hazards (Plate 3). Vulnerability being exposure, sensitivity and inability to adapt to the floods, landslides, rock fall and mass wasting that occurs on the valleys and steep slopes observed. In total 574 houses were counted that are vulnerable to floods.

The population living in risk zones is dominated by the poor. Poverty is defined in this context as a situation of deprivation or accumulation of handicaps (lacunes) that prevents a town dweller from taking advantage of existing opportunities to improve on his socio-economic welfare Ramonde (1989). Faced with this context the victims many of whom have been displaced from the heart of Yaounde city by urban renewal works and are unwilling to return to the countryside occupy these zones. The poverty context of the people exposes them on further risk as the precarious houses built on the slopes and marshland are incapable of resisting floods, rock falls, landslide and other types of hazards.

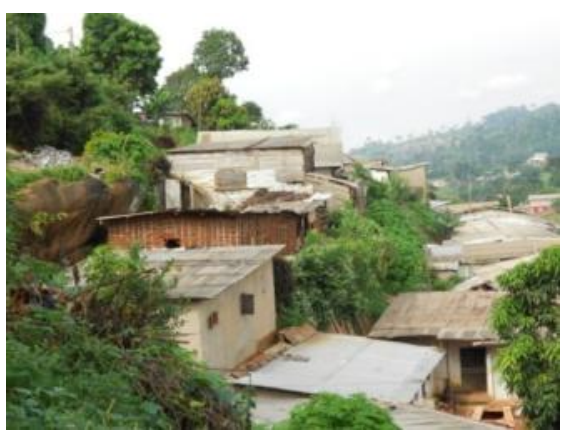

(a)

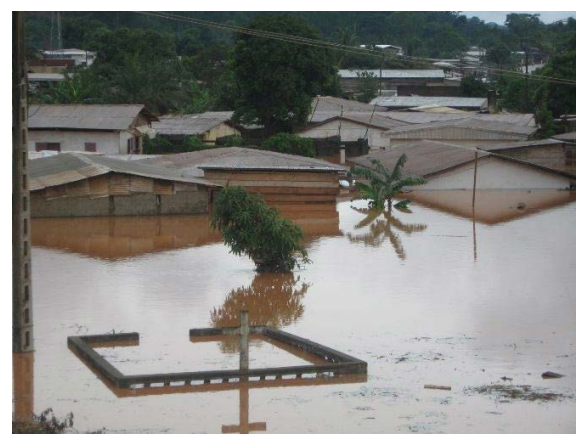

(b)

Plate 3. Urban front development on highly risky slope and flood prone valley. (a) Houses at risk of rock fall in Oliga and Photo. (b) Habitats submerged by water at Nkolbisong Area. In these areas, accessibility to houses is difficult as building construction do not respect the urban plan and norms. Source: Ojuku (2014), Photo Mengue A. M. and Kelvin N. (2016). 


\subsection{Front Development}

Mostly migrants searching for habitable and commercial land are involved in activities leading to this urban expansion. In Yaounde the local population has been pushed into the suburbs and distant fringed lands by relatively wealthy, enterprising and dynamic migrants comprising mostly the Bamileke of West Cameroon, Anglophones of the Northwest and Southwest regions, the Fulani population of northern Cameroon and the Bassa of the littoral regions. These people are either civil servants or business men that are relatively wealthy.

The process of establishment of urban fronts excites attention. First a piece of land is acquired in the outskirts of the town upon information reception from "demarches" or a tribal member of family. Depending on the financial status of the person involved the land is occupied. Demarcations are made with barbed wire or peace tree to secure the land where the land owner is poor. A farm is then established to secure the land from encroachment by neighbours or an unknown person. In some situations a small hurt or plank building "carrabout" is erected on the land to prevent it from being sold to another person. A relative is contracted to stay in the hurt temporary while taking care of the land. When money is available a more durable building is constructed using bricks, a well docked to provide water, electricity connected after negotiations with a neighbour and the family moved in. When new resources are available the person may buy a second plot to be resold in future or for an enterprise.

In most cases, relatives and friends are invited to buy plots in the area to live together with the first occupant. Gradually from information networks, a quarter is created dominated sometimes by people of the same ethnic belonging or social category. In these quarters houses look uncompleted, surrounded by farmlands and small informal business enterprises such as building material shops, food and drinking parlours, provisional stores and the first occupant crowned as an elder or notable. Sometimes the occupants faced with transport constraints to the heart of the town, may buy a motorbike or used car to travel. Others cover long distances on daily bases to the urban centres. Several urban fronts in North western Yaounde has evolved in this way.

\subsection{Signatures of Urban Disorder}

Many habitats in the study site are poor in basic services, hygiene and sanitation. Quarters do not have good quality water, access roads, waste disposal facilities, drainage ways, good toilets and electrical installations (Table 1). Several houses are constructed with scrap material, served by ill adapted latrines on the environment, have poor electrical installations and connections. Promiscuity and all forms of pollution and crime prevails in the occupied areas.

\subsection{Distribution of Health Care Services}

The health situation in the NW Mountains of Yaounde is precarious. The health infrastructures exist but inaccessible to many of the vulnerable poor populations (Figure 5). In Yaounde 1, there are 3 hospitals, 12 clinics, 31 medical centres, 
Table 1. Situation of hygiene and sanitation in north western Yaounde Mountains.

\begin{tabular}{|c|c|c|c|c|c|c|c|c|c|}
\hline \multirow[b]{2}{*}{ Locality } & \multirow{2}{*}{$\begin{array}{l}\text { Population } \\
\text { Sampled }\end{array}$} & \multicolumn{5}{|c|}{ Kitchen Waste Disposal (\%) } & \multicolumn{3}{|c|}{ Liquid (\%) } \\
\hline & & $\begin{array}{l}\text { Trash } \\
\text { Cans }\end{array}$ & Streams & $\begin{array}{c}\text { Open } \\
\text { Air }\end{array}$ & Pits & Farmland & Toilet & $\begin{array}{c}\text { Open } \\
\text { Air }\end{array}$ & Streams \\
\hline Oliga 1 & 12 & 20 & 25 & 5 & 10 & 40 & 25 & 60 & 15 \\
\hline Mbankolo & 18 & 5 & 30 & 15 & 20 & 35 & 30 & 40 & 30 \\
\hline Carriere-Messa & 8 & 10 & 0 & 20 & 40 & 30 & 60 & 30 & 10 \\
\hline Olinga-Camp S. & 15 & 5 & 25 & 35 & 10 & 25 & 35 & 45 & 20 \\
\hline Febe Village & 6 & 0 & 35 & 15 & 15 & 35 & 35 & 50 & 15 \\
\hline Melingui & 6 & 10 & 15 & 10 & 25 & 40 & 45 & 35 & 20 \\
\hline Nkolbisong & 15 & 5 & 25 & 35 & 5 & 30 & 10 & 70 & 20 \\
\hline Elig-Otoumba, & 5 & 2 & 8 & 45 & 15 & 30 & 10 & 75 & 15 \\
\hline Oyomabang, & 4 & 5 & 25 & 30 & 10 & 30 & 15 & 65 & 20 \\
\hline Angono, & 6 & 1 & 6 & 50 & 1 & 42 & 10 & 80 & 10 \\
\hline Nkolafeme & 7 & 0 & 0 & 70 & 0 & 20 & 30 & 60 & 10 \\
\hline
\end{tabular}

Source: Ojuku (2014) and field surveys 2016.

and 7 laboratories totalling 53. In Yaounde 2 there are 3 hospitals, 3 clinics, 41 medical centres, and 1 laboratory summing up to 48 health infrastructures. In Yaounde 7 none of these services exist. Paradoxically Yaounde 7 is the subdivision where risk of floods and landslides is very prevalent. Consequently, many people of the low income group resort to natural herds, traditional healers and roadside vendors of uninsured medication for healing. This amplifies the worsening situation.

\subsection{Risk Factors}

Floods are very recurrent in wetlands of North Western highlands of Yaounde. Firstly, they result from illegal occupation of valleys and marshy areas by populations and the haphazard construction of houses along water courses. Secondly, floods are caused by the establishment of informal business enterprises (wood sales, carpentry workshops, motor garages, bakeries, car wash points, piggeries, poultry firms and market gardens) along water courses and wetlands. Thirdly, the uncontrolled disposal of solid and liquid waste into streams and water ways (Table 1) and poorly executed drainage works by engineering companies are some of the factors of risk. Fourthly, the expansion of settlement, agricultural and commercial activities on hill slopes leads to deforestation of mountain slopes Nkwemoh et al. (2017). Deforestation accelerates run-off after torrential rainfall leading to water discharge into the surrounding valleys and floods Yongsi et al. (2008). Construction of houses on marshy areas and water courses is often accompanied by flood hazards in these hilly zones. This spontaneous colonisation of risk zones at the North Western Mountains of Yaounde and environs are manifested by deviation of water courses, reclamation of wetlands through filling with earth material, construction of embankments, filling of earth in plastic bags and pilling along water ways and gullies, pilling of old vehicle tyres 
along the stream and building of suspended house foundations along water ways to avoid flood risk (Figure 6, Plate 4).

In this figure one observes the dense concentration of settlement, farmlands, infrastructures (roads and equipments (health services) along the river valleys in green colour where flood risk often occurs. The buildings that appear in red are



Figure 6. Infrastructures and buildings installed at marshlands vulnerable to floods in the Northwestern Highlands of Yaounde. Source: Authors, 2016.

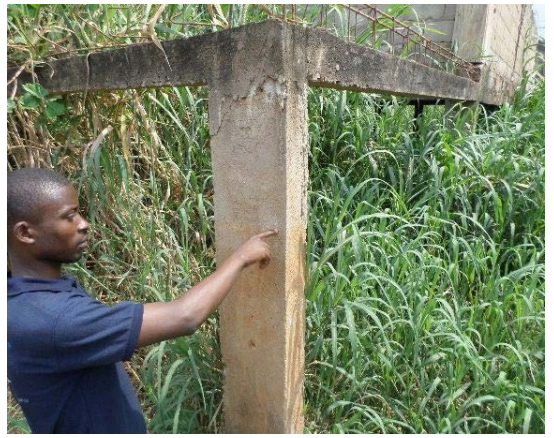

(a)

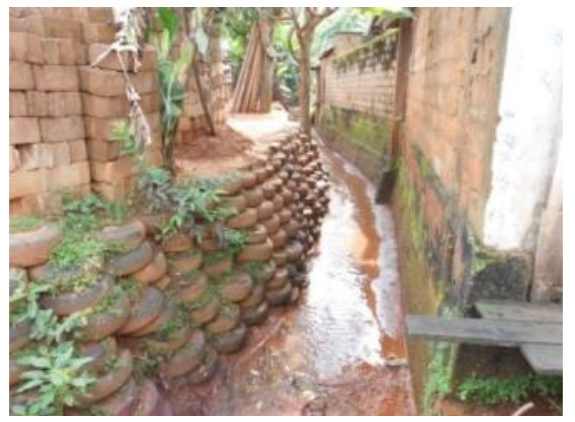

(b)

Plate 4. Defensive strategies against flood risk in Oyomabang wetlands-Messa neighbourhoods. (a) Raised foundation ready for construction on wetland. (b) Discarded motor tire used as flood embankment. Source: Photo A (Ojuku T. 2015) Photo B (George N. 2015). 
those affected by floods.

\section{Manifestation and Outcomes of Urban Front Disasters}

\subsection{Flood Risk}

Floods in the North Western Mountains of Yaounde are manifested in several ways. They are characterised by submersion of houses and destruction of equipments, water occupation of public infrastructures such as health service centres, schools, churches, administrative buildings and roads (Figure 7). Also, electricity and telecommunication poles are pulled down (Plate 5), public wells and toilets filled with water. Sometimes small scale informal business enterprises like poultry firms, carpentry workshops are also invaded by floods and investments carried away by water. Toilets are also flooded by water and water wells filled by sewage disposed from toilets. Populations affected by these floods often suffer from stigma from the public leading to psychological depression for living in risk zones

These scenarios are very rampant along valleys in North Western Highlands of Yaounde (Figure 7).

The outcomes of these floods are many and varied. They include loss of human lives, spread of epidemics Yongsi et al. (2008), soil erosion and large

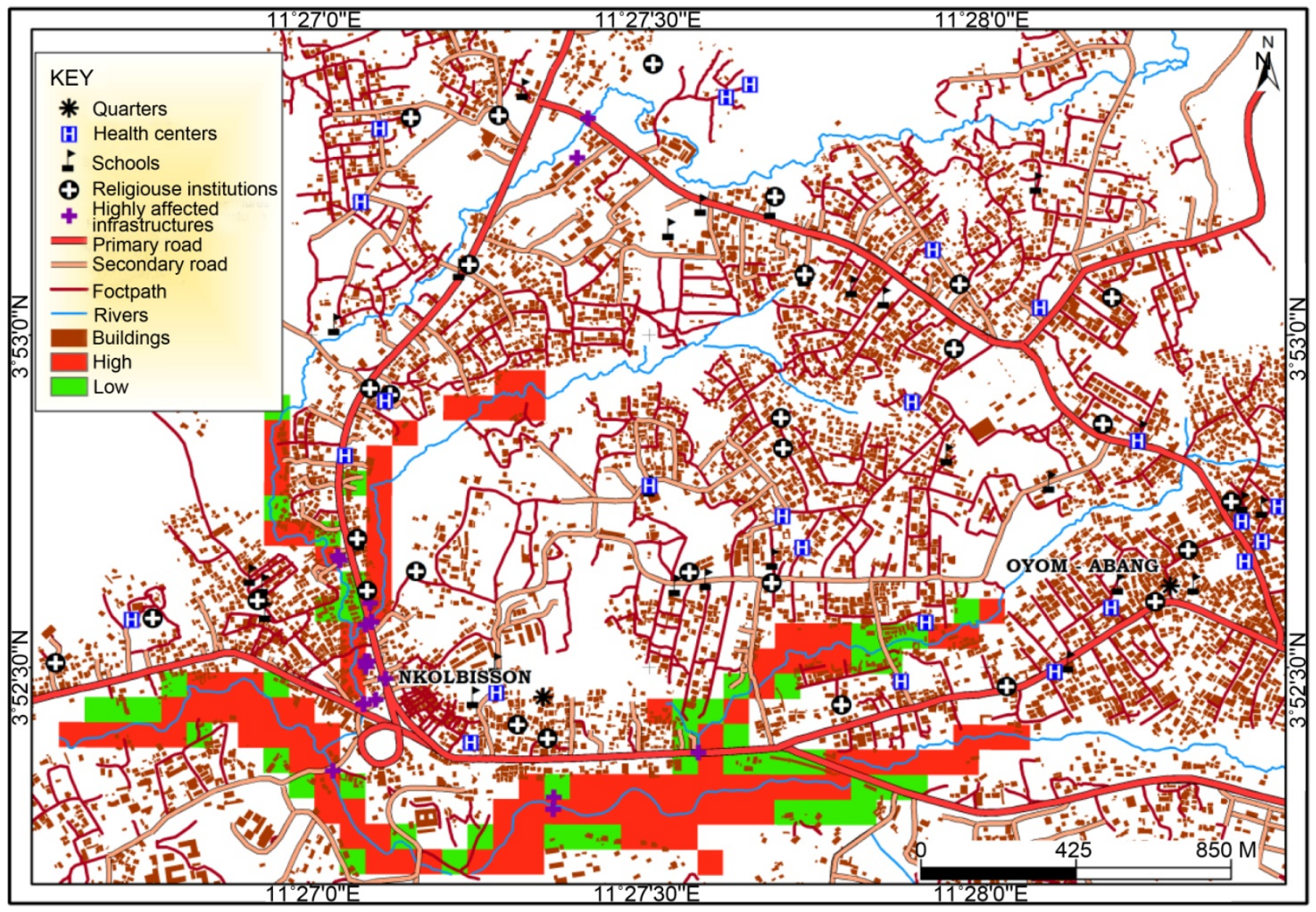

Figure 7. Urban sprawl, fronts, Infrastructures and buildings vulnerable to floods in the Northwestern Highlands of Yaounde. Source: Authors, 2016. 


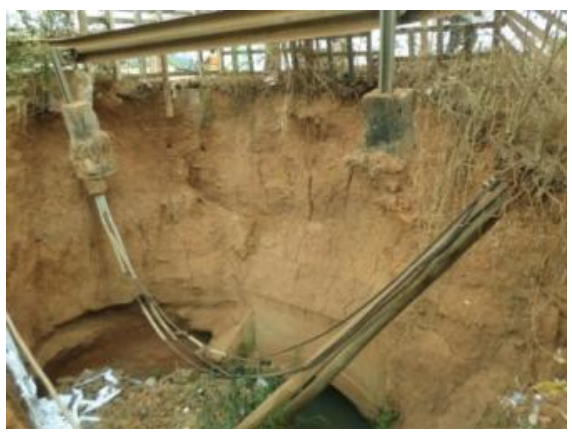

(a)

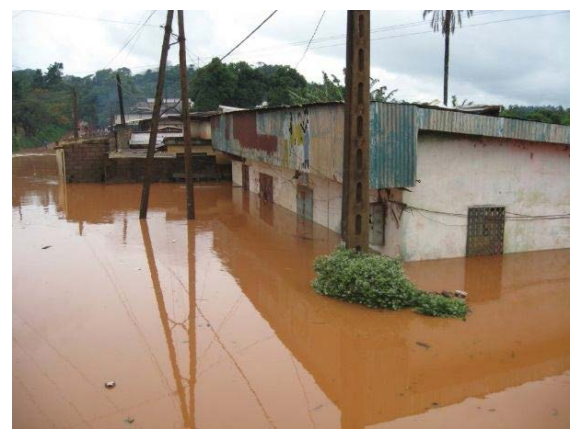

(b)

Plate 5. Electricity installations and road equipment destroyed by floods after rainstorm at the study site. (a) A road, equipments and brige damaged by floods at Nkolbisong. (b) Habitats under floods at Oyomabang. Source: Ojuku T. and Mengue A. (2016).

deposition of sediments along water courses, disruption of drainage systems, damage of water and hydro-electricity equipments, destruction of artifacts, and general slowdown of economic activities.

\subsection{Slope Risk}

This risk has been observed along the densely occupied slopes. Risk of landslides, rock falls, mass wasting is common resulting from urban agriculture practices along these fragile lands, deforestation for fuel wood, house construction works and the installation of business enterprises such as petit commerce, health services, churches, schools and other income generating activities on steep slopes. In the heart of rainy season, fatal landslides do occur in some places leading to loss of human lives and destruction of valuable property. A case in place were the Mbankolo rock falls incidences of 1986 when rocks measuring 5 $\mathrm{m}$ large by $2.5 \mathrm{~m}$ of thickness in August and another measuring $6 \mathrm{~m}$ large in September detached up hill and were only stopped by trees, created a lot of panic in the Oliga and Febe quarters. These sites now occupied had no population settlements at that time. Significant damages were done on food crops and cocoa farms evaluated at 900,000 FCFA (Ntsama, 2011). Also the Oyomabang landslides of 1990 cause a lot of damages on farmlands, houses and other valuable property. Despite warning by the state, the construction of low class, middle class and high class houses on these steep slopes is high (Plate 6 and Plate 7). Quarrying of rocks for sale and construction works is also common in the area.

Many rich people solicit high slope areas for habitation as a symbol of wealth. From these areas they can observe the beauty of the town, its landscapes and fine air breeze. The occupants are mostly migrants and highlanders from Western Cameroon. Some originate from Bafang, Bamboutos and Bangangte divisions where the occupation of hill summits is a culture. They wish to live aristocratic lifestyles typical of some countries of the North.

\section{Crumbling Solutions to Catastrophe Speculation}

Flood victims and other stakeholders have developed strategies to prevent the 


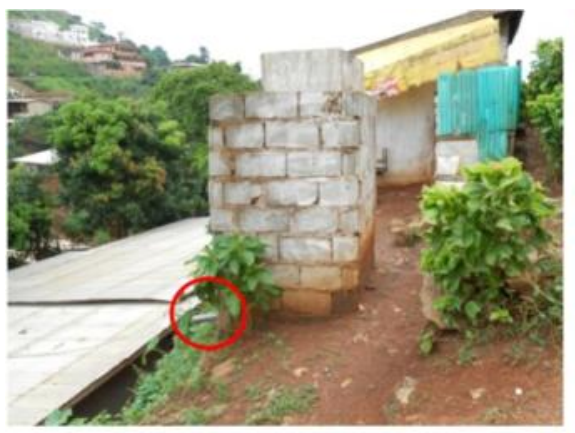

(a)

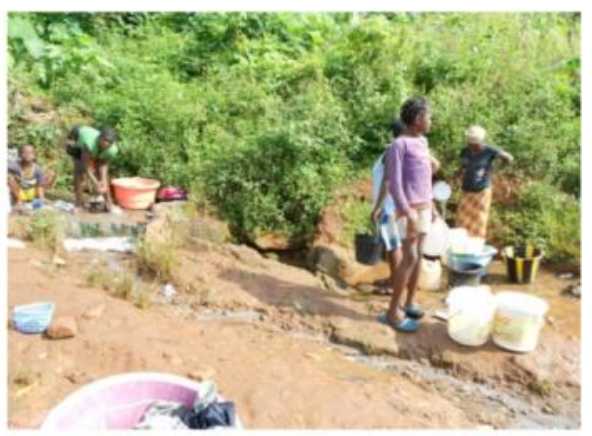

(b)

Plate 6. Pollution risk along hill Slopes at Carrier quarter and Mbankomo. (a) A latrine installed above a roof. Note the sewage discharge pipe pointing towards the roof of a neighbor. (b) Urban dwellers collecting water for domestic use on a contaminated stream at Mt Akok-Ndoue site. Source: Photo Ojuku T. (2015 and 2016).

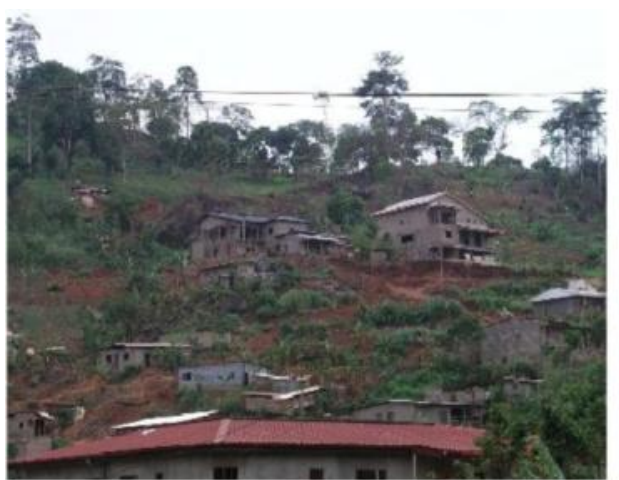

(a)

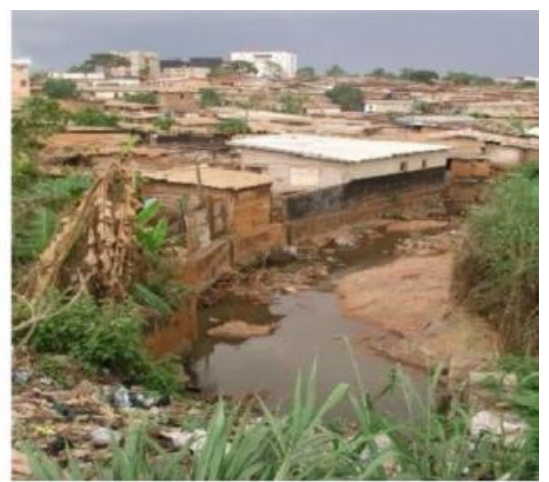

(b)

Plate 7. Slope and Marshland colonisation by Rich and Poor populations in the study site. (a) New front advancement along the Mount Mbankolo slopes. Note the quality of High-class buildings. (b) Colonisation of wetlands at Nkolbisong by an old front. Note the nature of Makeshift buildings. In these scenes the environmental impacts are visible characterised by deforestation and waste pollution of streams.

negative outcomes. These include the construction of embankments to defend against floods and building of high foundations before construction of houses. The city council has planted eucalyptus trees to drain the wetlands at Nkolbisong (Plate 8(a)), made a census of houses at risk and placed Red Cross marks on them for eventual demolition. Efforts have also been done to sensitize the population installed at risk zones about possible dangers on human lives and property (Plate $8(\mathrm{~b})$ ). In some situations buildings have been demolished in the area. Laws forbidding the installation of population and activities at these risk zones have been enacted by the government. These hard and software measures have had little success on the ground faced with rapid population growth and urban expansion, bad governance and endemic corruption practices that characterized the Cameroon public administration.

With regards to occupants of risky slope lands, different adaptation strategies have been adopted to prevent disasters. These are pilling of earth filled bags as embankments, planting of ornamental trees around buildings and the opening 


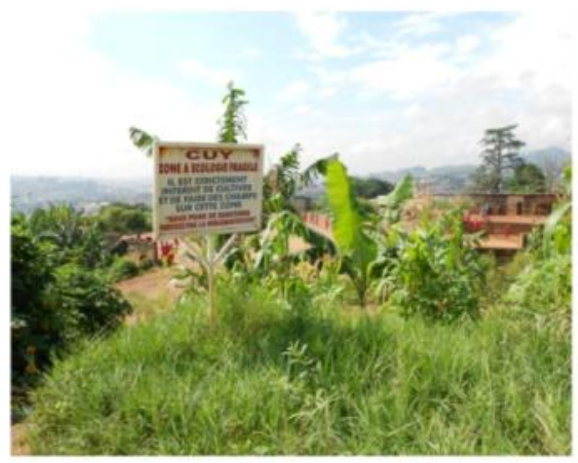

(a)

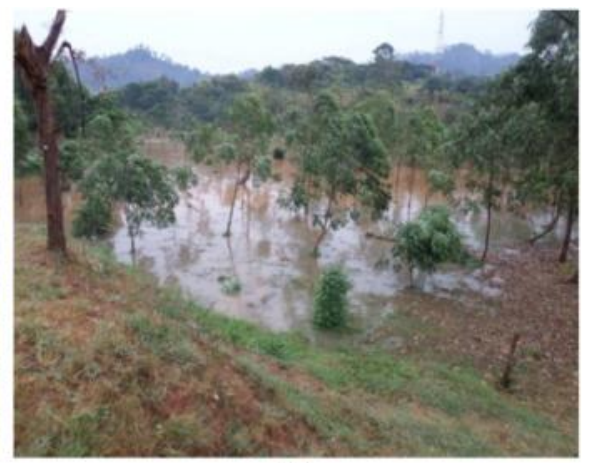

(b)

Plate 8. Sensitization and planting of eucalyptus to control the effects of floods on population and development. (a) A signboard placed at Carrier to stop hill slope occupation. (b) Eucalyptus trees planted to combat floods at Nkolbisong.

of large gullies to channel water after heavy rainfall. The measures are geared towards reducing possible hazards from landslides, rock falls, soil erosion that in the past have affected the Mbankolo, Oliga and Carrier areas.

\section{Discussion and Conclusion}

As many city dwellers and displaced persons from the Yaounde city centre live in the neighbourhoods, several of which are hazard areas, the new settlements are considered urban fronts. In this work we showed that these informal urban fronts develop along valleys and slopes vulnerable to floods and mass wasting hazards. A city that is sustainable cannot cope with this rising phenomenon. Many urban fronts and dynamics in the Messa Mountains of Yaounde are animated by a population without the capacity to cope in an eventual disaster. This necessitates government action and intervention to avoid a catastrophe. To understand urban fronts and their development on risk zones and how to direct policy on solving emerging outcomes, a GIS approach is indispensable. This method goes beyond conventional descriptive approaches which are no longer sufficient in characterizing as well as quantifying the phenomenon to precision for policy and less costly solutions in redressing the negative outcomes.

In terms of policy, the most recent urban planning project in Cameroon that affects the Messa Mountains is the "Yaounde 2020 plan directeur d'urbanisme (MINDUH and CUY, 2008)" which seeks to give Yaounde a new look by 2020. This plan seems even more dislocated from the daily life and urban front development and rapid expansion in the Messa Mountains and neighbourhoods than existing colonial plans of Yaounde. Houses, activities and enterprises continue to crop in anarchy in these risk prone areas, with occupants having land titles and building permits on lands occupied with the complicity of decision makers faced with a highly corrupt administration. Because of the exclusive character of these informal urban fronts, the occupants will never set foot out of the risk zones. This case study superimposes a new and emerging urban reality to cities in developing countries in their process of urbanization and urban fabric. 


\section{References}

Assako Assako, R. J. (1998). Apport de la télédétection et du SIG dans la recherche des zones constructibles d'un site urbain de collines, Le cas de Yaounde (Cameroun). Espace Géographique, 27, 122-128.

Bopda, A. (1985). La Dynamique de l'espace urbaine a Yaounde, Reconstruction et expansion post colonial du bati. These de Doctorat de 3eme cycle Universite de Yaounde.

BUCREP (2005). Recensements de la population camerounaise. CMR-BUCREPRGPH2005-V1.0

BUCREP (2010). Recensements de la population camerounaise. Presses du BUCREP, Yaounde.

Franqueville, A. (1984). Yaounde, Construire une Capital, Etudes Urbaines, ORSTOM.

MINDUH and CUY (2008). Yaounde 2020-Plan Directeur d'Urbanisme, Augea International-IRIS Conseil Arcauplan, Yaounde.

Mougoue, B. (1992). Croissance urbaine périphérique des Métropole Yaounde et Douala. Revue de Géographie du Cameroun, X1, 1-12.

Mveng, E. (1985). Histoire du Cameroun Tome II. Yaounde: CEPER.

Ngouanet, C. (2015). Périurbanisation anarchique et problématique de l'aménagement du territoire dans le périurbain de Yaounde, in «Territoires périurbains Développement, enjeux et perspectives dans les pays du Sud edited by Jan Bogaert, Jean-Marie Halleux, Les Presses Agronomiques de Gembloux, 259-270.

NIS, National Institute of Statistics. (2007). CAVIE: Enquête sur le cadre de vie des populations de Yaounde et Douala.

Nkwemoh, C. A., Mesmin, T., \& Afungang, R. N. (2017). The Impact of Urbanisation on the Vegetation of Yaounde, Cameroon. International Journal of Innovation Research and Development, 6, 6-18.

Ntsama, M. T. (2011). La Gestion des Eboulements sur les flancs du Mont Mbankolo, Mémoire de DIPES II, Ecole Normale Supérieure.

Ojuku, T. (2014). Contours of Urban Disorder and Health Hazards along Messa mountains (NW Yaounde) and Nylons of Douala Cameroon, in Urbanisation, environnement et Sante. International Journal of Advanced Studies and Research in Africa, 136.

Ramonde, S. P. (1989). Mythes égalitaires et pauvretés Une approche géographique Centre national de la recherche scientifique, Paris.

Vennetier, P. (1973). Problème de Croissance Urbaine dans le Monde Tropicale. Bordeaux: GEGET CNRS.

Yongsi, H. B. N. et al. (2008). Environmental Sanitation and Health Risks in Tropical Urban Settings: Case Study of Household Refuse and Diarrhoea in Yaounde, Cameroon. International Journal of Social Sciences, 3, 220. 
Submit or recommend next manuscript to SCIRP and we will provide best service for you:

Accepting pre-submission inquiries through Email, Facebook, LinkedIn, Twitter, etc. A wide selection of journals (inclusive of 9 subjects, more than 200 journals)

Providing 24-hour high-quality service

User-friendly online submission system

Fair and swift peer-review system

Efficient typesetting and proofreading procedure

Display of the result of downloads and visits, as well as the number of cited articles Maximum dissemination of your research work

Submit your manuscript at: http://papersubmission.scirp.org/

Or contact cus@scirp.org 